\title{
Seasonal Patterns of Ticks in Pocheon and Cheolwon, Republic of Korea
}

\author{
Yong Chil Shin ${ }^{1}$, In Yong Lee ${ }^{2}$, and Jang Hoon Seo ${ }^{1}$ \\ ${ }^{1}$ Department of Biomedical Laboratory Science, Shinhan University, Uijeongbu 11644, Korea \\ ${ }^{2}$ Institute of Tropical Medicine, Yonsei University College of Medicine, Seoul 03722, Korea
}

\section{경기도 포천, 강원도 철원지역에서 진드기의 계절적 발생 유형}

\author{
신용칠 ${ }^{1}$, 이인용 $^{2}$, 서장훈 $^{1}$ \\ ${ }^{1}$ 신한대학교 임상병리학과, ${ }^{2}$ 연세대학교 의과대학 열대의학 연구소
}

\begin{abstract}
The seasonal pattern of larvae, nymph and adult life stages for three tick species were studied for April-October, 2014. Haemaphysalis longicornis (610), Haemaphysalis flava (296) and Ixodes nipponensis (15) were collected from Pocheon by the dragging and flagging method. H.longicornis (254), H.flava (345) and I.nipponensis (15) were collected from Cheolwon in the same way. H.longicornis adults peaked in June while nymphs were more frequently collected from April through June. In contrast, H.longicornis larvae were collected only in September and October. H.flava adults were collected in April, September, and October while nymphs were collected from April through October. The nymphs peaked in April in Pocheon while May was the peak in Cheolwon. Larvae of H.longicornis and H.flava were collected only in September and October. I. nipponensis adults and nymphs were more frequently collected in April, while the larvae were not collected during that period. Collecting ticks by the dragging and flagging method provides estimates of population densities for life stages of the selected species and the associated disease risk. These results can be used to predict seasonal population densities of ticks and the prevalence of tick-borne pathogens.
\end{abstract}

Keywords: H.flava, H.longicornis, I.nipponensis, Tick

This is an Open Access article distributed under the terms of the Creative Commons Attribution Non-Commercial License (http://creativecommons.org/licenses/by-nc/4.0) which permits unrestricted non-commercial use, distribution, and reproduction in any medium, provided the original work is properly cited.

Copyright @ 2015 The Korean Society for Clinical Laboratory Science. All rights reserved.
Corresponding author: Jang Hoon Seo Department of Biomedical Laboratory Science, Shinhan University, Uijeongbu 11644, Korea Tel: 82-31-870-3707

E-mail: bio93sky@nate.com

Received: July 22, 2015 Revised 1 $1^{\text {st: }}$ August 21, 2015

Revised $2^{\text {nd }}$ : August 24, 2015 Accepted: August 25, 2015

\section{서 론}

참진드기는 사람이나 동물에 기생하며 흡혈을 하는 절지동물이 다. 참진드기류는 알, 유충, 자충, 성충 등의 4 가지 발육단계를 가지 고 있으며, 흡혈한 암컷은 숙주에게서 떨어져 나와 돌 밑, 흙덩이 밑, 벽 틈 등과 같이 은폐된 곳에서 한 번에 무수히 많은 알을 무더기 로 낳고 죽는다. 알에서는 유충(larva)이 부화하는데 풀잎이나 관목 위에 기어 올라가 적당한 숙주가 지나갈 때까지 기다렸다가 긴 앞 다리로 숙주에 달라 붙어 흡혈한다. 유충은 흡혈한 후 탈피하여 자 충(nymph)으로 발육하고, 다시 숙주에게 달라붙어 흡혈한 후 탈피 하여 성충으로 발육한다. 참진드기가 흡혈할 때 항응고제 등의 성 분이 함유된 타액을 숙주의 피부에 주입하게 되는데, 이 때 진드기 가 감염되어 있던 세균, 바이러스, 기생충 등이 숙주 체내로 함께 유 입되어 감염시키기 때문에 진드기가 매개체 역할을 한다(Shin, 2013). 참진드기는 3과 800 종 이상이 분포하고 있다. 참진드기는 리켓치아, 박테리아, 바이러스, 선충을 매개한다(Sonenshine, 1991; Piesman와 Eisen, 2008).

참진드기는 모기, 이, 벼룩 등에 비해 한 살이가 길고 숙주동물에 
긴 시간 머물며 피를 많이 흡혈하며 여러 가지 영향을 주고 있다. 참 진드기가 사람이나 동물 살갖에 주둥이를 오랜 시간 찔러 박고 흡 혈하여 살갖상처와 피부염, 독성반응, 알레르기 및 면역반응이 나 타나며 바이러스, 박테리아, 리켓치아, 곰팡이, 원충, 선충을 옮겨 주어 질병을 일으키고 경제손실과 생명을 위협한다(Lee, 2013). 국 내에서 참진드기가 매개하는 질병은 진드기매개티프스(tick-borne typhus), 진드기매개뇌염(tick-borne encephalitis), 라임병(Lyme disease), 아나플라즈마증(anaplasmosis), 에르리히증(Ehrlichiosis), 야토병(tularmia), 쥐바베스열원충증(babesiosis), 범안열원층증 (theileriasis), 중증열성혈소판감소증(severe fever with thrombocytopenia syndrome, SFTS)이 있다(Kee 등, 1992; Park 등, 1992; Hoe 등, 2002; Lee 등, 2003; Lee 등, 2005; Chung 등, 2006; Kim 등, 2007; Chae 등, 2008a; Chae 등, 2008b; Kim 등, 2008; Kim 등, 2009; Lee 등, 2010; Moon 등, 2013; Kim 등, 2013).

최근 들어, 우리나라는 수풀이 우거지고 야생동물 증가로 참진 드기 개체 수가 증가해서 작은소피참진드기(Haemaphysalis longicornis), 개피참진드기(Haemaphysalis flava), 산림참진드기(Ixodes persulcatus), 일본참진드기(Ixodes nipponensis)가 진드기매개 뇌염, 라임병, 일본홍반열, 아나플라즈마증, 에르리히증, 쥐바베스 열원충증, 중증열성혈소판감소증후군증 환자를 발생시켜서 사회 문제가 되고 있다(Lee, 2013).

중증열성혈소판감소증후군(Severe fever with thrombocytopenia syndrome, SFTS)은 2009 2010년에 중국 중동부지역과 북부지역 6개성(Liaoning, Shandong, Henan, Hbei, Anhui, Jiangsu) 에 걸쳐 원인을 알 수 없는 고열과 혈소판감소를 주증상으로 한 환 자들이 나타나, 이들에 대한 조사 결과가 2011년 New England Journal of Medicine에 보고됨으로써 세상에 알려졌다(Yu 등, 2011). 우리나라에서 중증열성혈소판감소증후군은 2013년 5월 일부의작은소피참진드기에서 SFTS 바이러스가 분리 확인 및 환자 가 확진되었으며 환자 발생은 경기 1 명, 강원 2 명, 경북 11 명, 충북 2명, 전남 5명, 경남 8명, 제주 6명에서 발생하였다(Park 등, 2014).

작은소피참진드기는 한국을 포함하여 중국, 몽골, 일본 등 동아 시아 전역에 걸쳐 오랫동안 서식해온 참진드기이다. 아직 국내에서 작은소피참진드기의 전국적인 SFTS 바이러스 감염률 조사는 이루 어지지 않았다.

중증열성혈소판감소증후군은 과거부터 우리나라에도 발생했 을 가능성이 있으며 앞으로는 매개체의 서식기간과 맞물려 계속 발 생할 것으로 예상되는 만큼 진드기 서식 실태조사를 세분화할 필요 가 있다.

따라서 본 연구는 경기 포천지역 및 강원 철원지역에서 참진드
기에 대한 분포를 조사하였다.

\section{재료 및 방법}

\section{1. 진드기 채집}

진드기 채집은 경기도 포천시 영중면 금주리 지역과 강원도 철 원군 서면 자등리 지역의 잡목 숲 등에서 2014년 4월부터 10월까 지 면으로 된 가로 $150 \mathrm{~cm}$ 세로 $100 \mathrm{~cm}$ 의 천을 이용하여 천끌기 (dragging)나 천젓기(flagging)로 진드기를 채집하였다. 채집된 진 드기는 종분류 시험전까지 $70 \%$ 에탄올에 넣어 보관하였다. 천끌기 와 천젓기 채집 결과, 개체군 밀도가 높은 지점을 선정하여 면적 $100 \times 100 \mathrm{~m}$ 에서 집중 발생밀도를 조사하여 종다양성 및 계절적 분포를 확인하였다.

\section{2. 진드기 종 분류 동정}

종 분류 동정은 $70 \%$ 알코올에 고정 보관된 진드기를 실체현미경 $(\times 10, \times 40)$ 을 이용하여 Ticks of Japan, Korea and the Ryukyu Islands (Yamaguti 등, 1971)에서 제시한 방법에 따라분류 동정하 였다.

\section{3. 진드기의 발육 단계별 및 월별 개체 변화 조사}

종 분류가 완료 된 진드기에서 발육 단계별(성충, 자충, 유충)에 대한 채집 개체 비율 변화 및 월별에 따른 채집 개체 비율을 비교 조 사하였다.

\section{결 과}

2014년 4월부터 10월까지 경기 포천지역과 강원 철원지역에서 채집된 진드기는 참진드기과(family Ixodidae)에 속하는 작은소 피참진드기(Haemaphysalis longicornis), 개피참진드기(Haemaphysalis flava)와 일본참진드기(Ixodes nipponensis) 등 3종이었 다. 조사기간 동안 경기 포천시 영중면 금주리에서 총 921개체가 채집되었다. 그중 작은소피참진드기는 성충 24 개체, 자충 174 개 체, 유충 412 개체가 채집되었고, 개피참진드기는 성충 10 개체, 자 충 69 개체, 유충 217 개체가 채집되었다. 일본참진드기는 성충 9 개 체, 자충 6 개체가 채집되었다. 또한 강원 철원군 서면 자등리에서 총 608 개체가 채집되었다. 그중 작은소피참진드기는 성충 23 개체, 자충 145 개체, 유충 80 개체가 채집되었고, 개피참진드기는 성충 4 개체, 자충 56 개체, 유충 285 개체가 채집되었다. 일본참진드기는 성충 12 개체, 자충 3 개체가 채집되었다.

포천지역에서 채집된 작은소피참진드기는 3 종 중 $66.2 \%$ 를 차 
Table 1. The total number and monthly mean number of larvae, nymphs, and adults of three tick species collected from Pocheon and Cheolwon, Republic of Korea, from April through October 2014

\begin{tabular}{|c|c|c|c|c|c|c|c|c|c|c|}
\hline \multirow{3}{*}{ Habitat } & \multirow{3}{*}{ month } & \multicolumn{9}{|c|}{ Species } \\
\hline & & \multicolumn{3}{|c|}{ Haemaphysalis longicornis } & \multicolumn{3}{|c|}{ Haemaphysalis flava } & \multicolumn{3}{|c|}{ Ixodes nipponensis } \\
\hline & & Adults & Nymphs & Larvae & Adults & Nymphs & Larvae & Adults & Nymphs & Larvae \\
\hline \multirow{9}{*}{$\begin{array}{l}\text { Gyeonggi } \\
\text { Pocheon }\end{array}$} & Apr & $0(0)$ & $22(44)$ & $0(0)$ & $1(2)$ & $22(44)$ & $0(0)$ & $3(6)$ & $3(6)$ & $0(0)$ \\
\hline & May & $0(0)$ & $30(90)$ & $0(0)$ & $0(0)$ & $3(9)$ & $0(0)$ & $1(3)$ & $0(0)$ & $0(0)$ \\
\hline & Jun & $6(12)$ & $7(14)$ & $0(0)$ & $0(0)$ & $2(4)$ & $0(0)$ & $0(0)$ & $0(0)$ & $0(0)$ \\
\hline & Jul & $0(0)$ & $7(14)$ & $0(0)$ & $0(0)$ & $1(2)$ & $0(0)$ & $0(0)$ & $0(0)$ & $0(0)$ \\
\hline & Aug & $0.5(1)$ & $0.5(1)$ & $0(0)$ & $0(0)$ & $0(0)$ & $0(0)$ & $0(0)$ & $0(0)$ & $0(0)$ \\
\hline & Sep & $4(8)$ & $3.5(7)$ & $182(364)$ & $0.5(1)$ & $0(0)$ & $17.5(35)$ & $0(0)$ & $0(0)$ & $0(0)$ \\
\hline & Oct & $1.5(3)$ & $2(4)$ & $24(48)$ & $3.5(7)$ & $5(10)$ & 91 (182) & $0(0)$ & $0(0)$ & $0(0)$ \\
\hline & $\begin{array}{l}\text { Mean (Total) } \\
\text { Number }\end{array}$ & $1.6(24)$ & $11.6(174)$ & $27.5(412)$ & $0.6(10)$ & $46(69)$ & $14.5(217)$ & $0.6(9)$ & $0.4(6)$ & $0(0)$ \\
\hline & $\begin{array}{l}\text { Percent by } \\
\text { habitats (\%) }\end{array}$ & 3.9 & 28.5 & 67.6 & 3.4 & 23.3 & 73.3 & 60 & 40 & 0 \\
\hline \multirow{9}{*}{$\begin{array}{l}\text { Gangwon } \\
\text { Cheolwon }\end{array}$} & Apr & $0(0)$ & $26(52)$ & $0(0)$ & $1(2)$ & $1(2)$ & $0(0)$ & $3(6)$ & $1(2)$ & $0(0)$ \\
\hline & May & $1(3)$ & $8(24)$ & $0(0)$ & $0(0)$ & $9(27)$ & $0(0)$ & $2(6)$ & $0(0)$ & $0(0)$ \\
\hline & Jun & $6(12)$ & $25(50)$ & $0(0)$ & $0(0)$ & 7 (14) & $0(0)$ & $0(0)$ & $0.5(1)$ & $0(0)$ \\
\hline & Jul & $0(0)$ & $2(4)$ & $0(0)$ & $0(0)$ & $2(4)$ & $0(0)$ & $0(0)$ & $0(0)$ & $0(0)$ \\
\hline & Aug & $1(2)$ & $1(2)$ & $0(0)$ & $0(0)$ & $1(2)$ & $0(0)$ & $0(0)$ & $0(0)$ & $0(0)$ \\
\hline & Sep & $3(6)$ & $2.5(5)$ & $34(68)$ & $1(2)$ & $1.5(3)$ & $11(22)$ & $0(0)$ & $0(0)$ & $0(0)$ \\
\hline & Oct & $0(0)$ & $4(8)$ & $6(12)$ & $0(0)$ & $2(4)$ & $132(263)$ & $0(0)$ & $0(0)$ & $0(0)$ \\
\hline & $\begin{array}{l}\text { Mean (Total) } \\
\text { Number }\end{array}$ & $1.5(23)$ & 9.7 (145) & $5.4(80)$ & $0.3(4)$ & $3.7(56)$ & 19 (285) & $0.8(12)$ & $0.2(3)$ & $0(0)$ \\
\hline & $\begin{array}{l}\text { Percent by } \\
\text { habitats (\%) }\end{array}$ & 9.2 & 58.5 & 32.3 & 1.2 & 16.2 & 82.6 & 80 & 20 & 0 \\
\hline
\end{tabular}
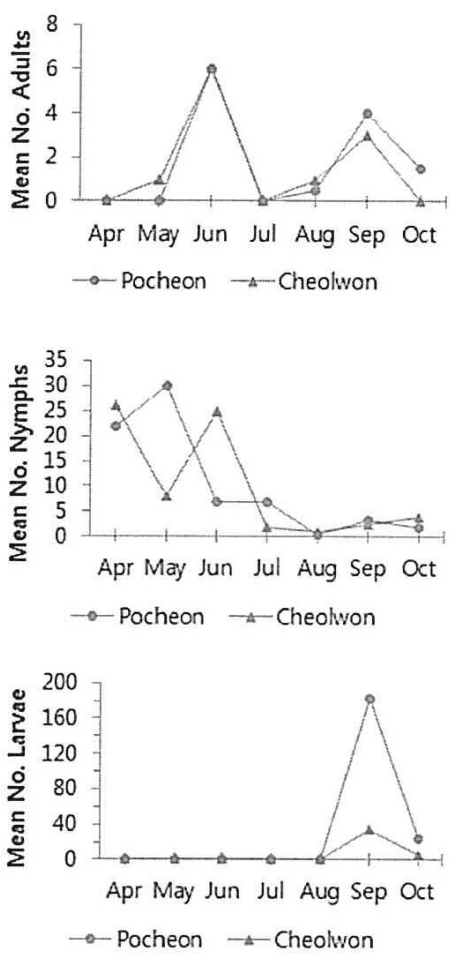

(A) Haemaphysalis longicornis
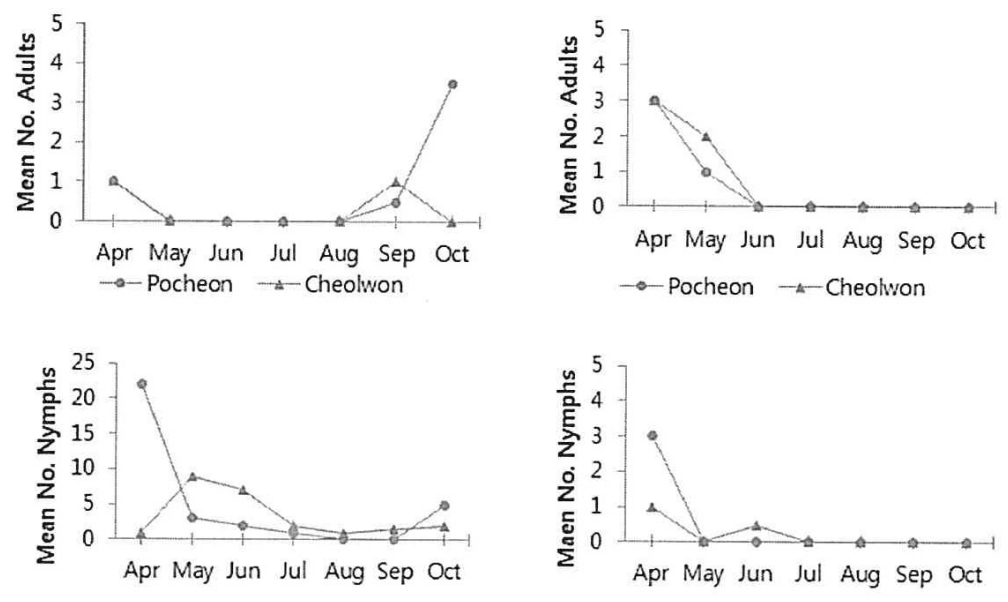

$\rightarrow$ Pocheon $\rightarrow$ Cheolwon
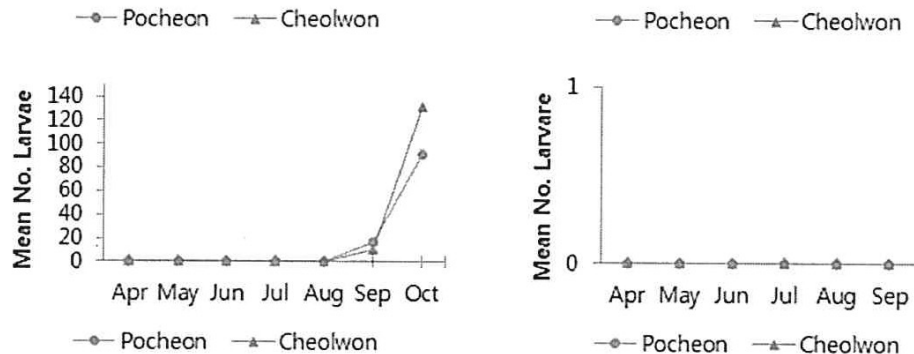

(B) Haemaphysalis flava

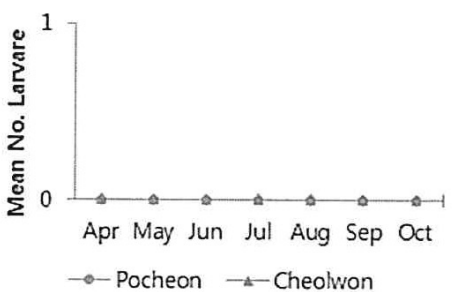

(C) Ixodes nipponensis

Fig. 1. Seasonal pattern of larvae, nymphs, and adults of three tick species collected by dragging and sweeping method from Pocheon and Cheolwon, Republic of Korea, for 2014. 
지하여 가장 많았고, 개피참진드기가 $32.2 \%$, 일본참진드기가 $1.6 \%$ 를 차지하였다.

철원지역에서 개피참진드기가 $56.7 \%$ 를 차지하여 가장 많았고, 작은소피참진드기는 3 종 중 $40.8 \%$, 일본참진드기가 $2.5 \%$ 를 차지 하였다(Table 1).

작은소피참진드기의 발육단계에 따른 계절별 채집비율을 보면 성충은 포천과 철원지역에서 6월과 4월에 각각 최고치를 나타내었 다. 작은소피참진드기 자충은 9 월과 10 월을 제외하고 다른 발육단 계 개체보다 높은 채집비율을 보이면서 포천에서는 4월과 5월 그 리고 철원에서는 4월과 6월에 높은치를 나타내었다. 작은소피참진 드기 유충은 두 지역 모두 9월에 채집되기 시작하며 10월에 다른 발 육단계보다 월등하게 많은 개체가 채집되었다.

개피참진드기의 발육단계에 따른 계절별 채집비율을 보면 성충 은 포천에서 10 월에 최고치를 보였고 철원에서는 4월과 9월에 채 집되었다. 개피참진드기의 자충은 작은소피참진드기의 자충과 유 사하게 4월-6월 사이에 주로 채집되었다. 개피참진드기의 유충은 9월에 채집되기 시작하여 10 월에 급격히 많은 개체가 채집되었다.

반면에 일본참진드기의 유충은 전기간 채집되지 않았고 성충과 자충 모두 4 6월 사이에 적은 수가 채집되었다(Fig. 1).

\section{고 찰}

참진드기는 계절 발생과 지역 분포가 온도, 습도, 숙주동물에 따 라 다르게 나타난다. 계절 발생은 봄철(4월 7월)과 가을철(9월 10 월)에 많은 개체가 나타나고 여름철에 적은 개체가 발생한다 (Kim 등, 2011). 눈이 많이 내린 겨울은 눈 이불효과로 겨울나기가 쉽고 이듬해 봄은 습도가 잘 유지되어 참진드기 발생밀도가 봄철에 높아진다. 지역 분포는 지역에 사는 숙주동물의 특성과 식생에 따 라 다르게 나타난다. 동물 종다양성이 있는 지역에서는 진드기 개 체군 밀도가 높고 종다양성도 높다. 참진드기과(Ixodidae)는 숙주 동물에 장시간 기생하고 있어서 숙주동물의 이동거리에 따라 넓게 분산되지만 단위 면적당 개체밀도는 낮고 물렁진드기과(Argasidae) 는 숙주동물에 기생하는 시간이 짧아 숙주동물 서식처에서 개체군 밀도가 높게 나타난다. 참진드기 분산거리는 생태와 질병을 규명하 는데 중요하다(Lee, 2013).

최근 중국과 일본, 그리고 한국에서 살인진드기로 알려진 작은 소피참진드기는 우리나라와 중국, 일본 등과 같은 아시아 지역에 널리 분포하고 있다. 특히 우리나라의 경우 산림에 가장 널리 분포 하고 있는 종류 중의 하나이다. 우리나라 산림과 수풀, 야생동물 및 가축에 분포하는 참진드기에 대한 분포조사는 그리 흔하지는 않지 만 2001년도와 2003년도 사이에 미군 주둔지 및 야외 훈련지 주위
의 동물과 수풀에서 채집한 참진드기 조사가 있는데, 총 1,638 마리 의 진드기에서 5 종의 진드기가 동정되었고, 그 중 작은소피참진드 기가 1,503마리로 $91.8 \%$ 를 차지하였다(Kim 등, 2006).

2007년에서 2008년 사이에 제주지역에서 진드기 채집 결과를 보면 참진드기과(family Ixodidae), 피참진드기속(Genus Haemaphysalis)에 속하는 개피참진드기(Haemaphysalis flava)와 작은 소피참진드기(H. longicornis) 등 2종이었다. 조사기간 동안 총 72 개 지점에서 3,089 개체가 채집되었는데 그 중 개피참진드기 $(H$. flava)는 3 개체, 나머지 3,086 개체는 모두 작은소피참진드기 $(H$. longicornis)가 채집되었다. 또한 작은소피참진드기는 조사지점 모두에서 채집되었다(Moon 등, 2008).

2004 2005년 DMZ 인근지역의 수풀에서 채집된 전체 진드기 중 작은소피참진드기가 $98.9 \%$ 가 채집된 반면 개피참진드기는 주 로 낙엽수 밀집지역(60.2\%)과 침엽수 밀집지역(57.4\%)에서 주로 채집되었다. 일본참진드기는 낙엽수 밀집지역보다 침엽수 밀집지 역에서 주로 채집되었다(Chong 등, 2013).

중증열성혈소판감소증후군의 주요 증상은 지속되는 고열, 소화 기 증상, 혈소판 감소, 백혈구 감소, 림프절 종대 등이며 중증 사례 의 경우 신경계증상, 파종성혈관내응고증, 다발성 장기부전으로 진행하여 사망에 이르기도 한다. 본 질환은 쯔쯔가무시증, 신증후 군출혈열, 렙토스피라증, 라임병, 아나플라스마증 등과 감별해야 하며, 잠복기는 6 14일로 보고되었다(Kim 등, 2012; Liu 등, 2012).

현재까지 이 질환은 주로 매개체를 통해 전파되는 것으로 알려 져 있으며, 가장 대표적인 매개체는 작은소피참진드기이다. 이 진 드기는 과거부터 우리나라를 비롯하여 동북아시아 지역 및 오세아 니아 지역의 주로 온대지방에 걸쳐 분포해 온 진드기이다. 진드기 에 물린다고 해도 대부분 아무런 증상이 없고, 질환에 잘 이환되지 도 않는다. 질병관리본부/국립보건연구원이 과거 전국적으로 채 집한 진드기를 대상으로 조사해본 결과, 작은소피참진드기는 우리 나라 전역에 비교적 고르게 분포하며, 이중 SFTS 바이러스를 보유 하고 있는 진드기는 약 $0.5 \%$ 정도로 추산된다(Shin, 2013).

지구 온난화 현상과 급격한 환경변화로 인하여 진드기 매개성 질환이 세계적으로 증가하고 있을 뿐만 아니라 사람과 동물에도 심 각한 질병을 유발하고 있다. 또한 계절에 따라 진드기의 출현 정도 가 다르기 때문에 이에 대한 진드기 매개성 질병의 발현 정도에 대 해서도 변화가 있을 수 있다고 추정할 수 있다.

따라서 본 연구에서는 경기도 포천 영중면지역과 강원도 철원 서면지역에서 질병매개 주요 참드기인 작은소피참진드기, 개피참 진드기, 일본참진드기 등 3 종을 채집하여 성충 뿐만 아니라 자충, 유충 등 발육단계별로 계절적 발생유형을 조사하였다. 
포천지역에서 채집된 참진드기 중 작은소피참진드기가 가장 많 았으며 철원지역에서는 개피참진드기가 가장 많았다. 제주지역에 서는 작은소피참진드기가 $99 \%$ 이상 채집되어(Moon 등, 2008) 지 역별로 우점종에 차이가 있었다.

작은소피참진드기 자충의 개체 수는 포천에서는 5월에, 철원에 서는 6월에 증가하였고 개피참진드기 자충의 개체 수는 포천에서 는 4월에 철원에서는 5월에 증가한 반면 일본참진드기 자충은 두 지역 모두 4월에 많았다.

또한 유충의 경우 포천에서 작은소피참진드기 유충의 개체 수는 9월에 급격히 증가 하였으며 철원에서는 개피참진드기의 유충의 개체수가 10 월에 급격히 증가하여 발육단계와 시기 그리고 지역별 차이가 있었다.

최근들어 한국은 기후온난화와 야생동물의 증가로 전국 전역에 진드기 매개 질병이 유행할 수 있는 만큼 경란전염 잠재성을 예측 할 수 있는 진드기의 계절적 발생 유형 및 진드기 서식 실태를 세분 화하여 조사하는 것은 필수적이다. 이번 결과는 조사지역의 진드기 의 밀도평가 뿐만 아니라 진드기와 연관된 질병 위험도를 예측하고 평가하는데 이용 할 수 있다.

\section{요 약}

참진드기 3종류의 발육단계별 즉 유충, 자충, 성충에 대한 계절 적 발생 유형을 2014년 4월에서 10월까지 조사하였다. 천끌기와 천젓기 방법으로 포천 영중면 금주리에서 작은소피참진드기 610 개체, 개피참진드기 296 개체 그리고 일본참진드기 15 개체가 채집 되었으며 같은 방법으로 철원 서면 자등리에서는 작은소피참진드 기 254 개체, 개피참진드기 345 개체, 일본참진드기 15 개체가 채집 되었다. 작은소피참진드기의 성충은 6 월에 가장 높은 채집 비율을 보였으며 자충은 4월에서 6월사이에 주로 채집되었다. 반대로 작 은소피참진드기의 유충은 9월과 10 월에만 채집되었다. 개피참진 드기의 성충은 4 월, 9 월, 10 월에 채집된 반면 자충은 4 월부터 10 월 까지 채집되었다. 개피참진드기의 자충은 포천에서는 4 월에 그리 고 철원에서는 5월에 가장 많이 채집되었다. 개피참진드기의 유충 은 작은소피참진드기의 유충과 같이 9월과 10 월에만 채집되었다. 일본 참진드기의 성충과 자충은 주로 4월에 채집되었으나 유충은 채집되지 않았다. 천끌기과 천젓기 방법으로 채집된 특정한 진드기 종의 발육단계별 밀도를 조사한 결과는 진드기의 계절별 밀도 평가 와 진드기 매개 질병 위험 분석에 활용할 수 있다.

\section{Acknowledgements: None}

Funding: None

Conflict of interest: None

\section{References}

1. Chae JS, Adjemian JZ, Kim HC, Ko SJ, Klein TA, Foley J. Predicting the emergence of tick-borne infections based on climatic changes in Korea. Vector Borne Zoonot Dis. 2008a,8(1): 265-275.

2. Chae JS, Yu DH, Shringi S, Klein TA, Kim HC, Chong ST, et al. Microbial pathogens in ticks, rodents, and a shaw in northern Gyeonggi-do near the DMZ, Korea. J Vet Sci. 2008b,9(3):285-293.

3. Chong ST, Kim HC, Lee IY, Kollars TM, Sancho AR, Sames WJ, et al. Seasonal distribution of ticks in four habitats hear the demilitarized zone, Gyeonggi-do (province), Republic of Korea. Korean J Parasitol. 2013,51(3):319-325.

4. Chung MH, Lee SH, Kim MJ, Lee JH, Kim ES, Lee JS, et al. Japanese spotted fever, South Korea. Emerg Infect Dis. 2006, 12(7):1122-1124.

5. Heo EJ, Park JH, Koo JR, Park MS, Park MY, Dumler JS, et al. Serological and molecular detection of Ehrlichia chaffeensis and Anaplasma phagocytophila (human granulocytic ehrilichiosis agent) in korean patients. J Clin Microbiol. 2002,40(8): 3082-3085.

6. Kee SH, Hwang KJ, Oh HB, Kim MB, Shim JC, Ree HI, et al. Isolation and identification of Borrelia burgdorferi in Korea. $J$ Korean Soc Microbio. 1994,29(4):301-310.

7. Kim CM, Yi YH, Yu DH, Lee MJ, Cho MR, Desai AR, et al. Tick-borne rickettsial pathogens in ticks and small mammals in Korea. Applied and Environmental Microbiology. 2006,72: 5766-5776.

8. Kim HC, Han SH, Chong ST, Klein TA, Choi CY, Nam HY, et al. Ticks collected from selected mammalian hosts surveyed in the Republic of Korea during 2008-2009. Korean J Parasitol. 2011, 49(3):331-335.

9. Kim JY, Cho SH, Joo HN, Tsuji M, Cho SR, Park IJ, et al. First case of human babesiosis in Korea: detection and characterization of a novel type of babesia sp. (KO1) similar to ovine babesia. J Clin Microbiol. 2007,45(6):2084-2087.

10. Kim KH, Yi J, Kim G. Severe fever with thrombocypenia syndrome. Emerg Infect Dis. 2012,19(11):1892-1894.

11. Kim SY, Yun SM, Han MG, Lee IY, Lee NY, Jeong YE, et al. Isolation of tick-borne encephalitis viruses from wild rodents, South Korea. Vector Borne Zoonotic Dis. 2008,8(1):7-13.

12. Lee DW. Severe fever with trombocytopenia syndrome minireview. Biosafety Newsletters. 2013,29:5-6.

13. Lee IY. Hard tick. AMIB Newsletter. 2013,7:1-4.

14. Lee JH, Park HS, Jung KD, Jang WJ, Koh SE, Kang SS, et al. Identification of the spotted fever group rickettsiae detected from Haemaphysalis longicornis in Korea. Microbiol Immunol. 2003,47(4):301-304.

15. Lee SO, Na DK, Kim CM, Li YH, Cho YH Park JH, et al. Identification and prevalence of Ehrlichia chaffeensis infection in Haemaphysalis longicornis ticks from Korea by PCR, sequencing and phylogentic analysis based on 16S r RNA gene. $J$ Vet Sci. 2005,6(2):151-155.

16. Liu Y, Li Q, Hu W, Wu J, Wang Y, Mei L, et al. Person-to-person transmission of severe fever with thrombocytopenia syndrome virus. Vector Borne Zoonotic Dis. 2012,12(2):156-160.

17. Moon BC, Shin EH, Kim YJ, Kim YJ, Im JS, Hong NY, et al. 
Idenitification and prevalence of rickettsial pathogen infection and geographical distribution of ticks in Jeju Island. Report of JERI. 2008,1:15-29.

18. Moon SJ, Gwack J, Hwang KJ, Kwon DH, Kim SY, Noh YT, et al. Autochthonous lyme borreliosis in humans and ticks in Korea. Osong Public Health Res Perspect. 2013,4(1):52-56.

19. Park KH, Lee SH, Won WJ, Jang WJ, Jang WH. Isolation of Borrelia burgdorferi, the causative agent of lyme diseases, from ixodes ticks in Korea. J Korean Soc Microbiol. 1992,27(4):307312.

20. Park SW, Han MG, Yun SM, Park C, Lee WJ, Ryou Js. Sever fever with thrombocytopenia syndrome virus, South Korea, 2013. Emerg Infect Dis. 2014,20(11):1880-1882.
21. Piesman J and Eisen L. Prevention of tick-borne diseases. Annu Rev Entomol. 2008,53:323-343.

22. Shin SS. Severe fever with thrombocytopenia syndrome virus. $J$ Korean Vet Med Assoc. 2013,49(6):359-364.

23. Sonenshine DE. Biology of ticks. 1991,p34-96 Oxford University Press Inc, New York.

24. Yamaguti N, Tipton VJ, Keegan HI, Toshioka S. Ticks of Japan, Korea and the Ryukyu Islands. Brigham Young Univ Sci Bull. 1971,15:1-226

25. Yu XJ, Liang MF, Zhang SY, Liu Y, Li JD, Sun YL, et al. Fever with thrombocytopenia associated with a novel bunyavirus in China. N Engl J Med. 2011,364(16):1523-1532. 